Jurnal IImiah ManajemenUbhara

\title{
PENGARUH KEPERCAYAAN DAN ULASAN PRODUK TERHADAP MINAT 62 BELI ULANG EMINA PADA OFFICIAL STORE SHOPEE DI KOTA SURABAYA
}

\author{
Khowin Ardianto'; Fania Putri Nuriska²; Lia Nirawati3 \\ Fakultas Ekonomi dan Bisnis Universitas Pembangunan Nasional "Veteran" Jawa Timur",2,3 \\ ardiantokhowin@gmail.com ${ }^{\text {; }}$ faniaputrin@gmail.com²; lianirawati@ymail.com ${ }^{3}$
}

\begin{abstract}
ABSTRAK
Penelitian ini bertujuan untuk mengetahui pengaruh kepercayaan dan ulasan produk terhadap minat beli ulang Emina pada official store Shopee di Kota Surabaya. Metode penelitian yang digunakan adalah metode penelitian kuantitatif. Sampel yang dipakai dalam penelitian ini sebanyak 100 responden yang diperoleh menggunakan metode purposive sampling. Pengumpulan data dilakukan dengan menggunakan kuesioner melalui google form. Metode pengujian data yang digunakan dalam penelitian ini yaitu uji validitas, uji reliabilitas, uji asumsi klasik, analisis regresi linier berganda, koefisien determinasi, uji t, serta uji F. Perhitungan data menggunakan software SPSS 25. Berdasarkan analisa data diperoleh hasil yang menyatakan bahwa kepercayaan memiliki pengaruh positif dan signifikan terhadap minat beli ulang Emina pada Official Store Shopee di Kota Surabaya. Sedangkan ulasan produk tidak memiliki pengaruh positif terhadap minat beli ulang Emina pada Official Store Shopee di Kota Surabaya. Variabel kepercayaan merupakan variabel yang berpengaruh paling dominan terhadap minat beli ulang Emina pada Official Store Shopee di Kota Surabaya.
\end{abstract}

Kata Kunci: Kepercayaan, Ulasan Produk dan Minat Beli Ulang

\section{ABSTRACT}

The aim of this research is to investigate the influence of trust and product reviews on Emina's repurchase interest at the Shopee Official Store in Surabaya. The research method used is quantitative research methods. The sample used in this study were 100 respondents who were obtained using purposive sampling method. The main instrument for data collection in this study is through questionnaire.via google form. Analysis of the data used are validity test, reliability test, classical assumption test, multiple linear regression analysis, coefficient of determination, $t$ test, and $F$ test. Calculation of data using SPSS version 25 software. The result of the study shows that trust have a positive and significant influence on Emina's repurchase interest at the Shopee Official Store in Surabaya. While product reviews do not have positive influence on Emina's repurchase interest at the Shopee Official Store in Surabaya. Trust variable is the variable that has the most dominant influence on Emina's repurchase interest at the Shopee Official Store in Surabaya

Keywords: Trust, Product Reviews and Repurchase Interest

Diterima: 1 September 2020; Direvisi: 20 September 202O; Diterbitkan: 1 Oktober 2020 


\section{PENDAHULUAN}

\begin{abstract}
Perubahan gaya hidup masyarakat yang semakin modern menuntut kesempurnaan dalam berbagai aspek, salah satunya adalah penampilan. Pemakaian perawatan yang sedang digemari oleh masyarakat, khususnya wanita adalah kosmetik untuk menunjang penampilan mereka. Kosmetik merupakan perawatan yang ditawarkan untuk meningkatkan kepercayaan diri. Kosmetik dapat mengubah penampilan tanpa mempengaruhi struktur tubuh penggunanya. Seiring dengan perkembangan zaman, perilaku penggunaan kosmetik mulai berubah. Kosmetik mulai digunakan dari kalangan remaja hingga dewasa dalam aktivitasnya. Selain itu, kosmetik saat ini bukan lagi kebutuhan sekunder, namun telah berubah menjadi kebutuhan dasar wanita agar terlihat lebih menarik. Bagi wanita, produk kosmetik selalu menjadi bagian dari kehidupan sehari-harinya untuk mendapatkan dan menjaga kecantikan dari waktu ke waktu.
\end{abstract}

Perilaku penggunaan kosmetik juga berubah, dapat dilihat dengan pertumbuhan industri kosmetik yang signifikan, ini menyesuaikan dengan permintaan konsumen yang semakin tinggi. Perubahan gaya hidup generasi muda atau milenial ini juga turut mendongkrak industri kosmetik. Persatuan Perusahaan Kosmetika Indonesia (Perkosmi) meyakini industri kosmetik tanah air akan terus tumbuh positif seiring dengan peningkatan permintaan, khususnya dari konsumen kelas menengah yang jumlahnya semakin besar. Direktur IKM Kimia, Sandang, Kerajinan dan Industri Aneka Kemenperin E Ratna Utarianingrum, optimis pertumbuhan industri kosmetik tahun 2020 akan tembus 9 persen, di mana pada 2019 angkanya ditargetkan mencapai 7,5 persen (SuaraKarya.id).

Permintaan kosmetik yang tumbuh signifikan ini menjadi peluang bagi industri kosmetik lokal. Dilansir dari (www.kemenperin.go.id) hingga tahun 2019 pemerintah mencatat ada 797 industri kosmetik besar dan industri kecil dan menengah (IKM) di Indonesia. Angka ini naik dari 760 perusahaan pada tahun 2018. Dengan begitu ada banyak pendatang produsen kosmetik baru dalam negeri. Pertumbuhan industri dapat dilihat dari banyaknya jumlah registrasi produk pada BPOM (Badan Pengawas Obat dan Makanan).

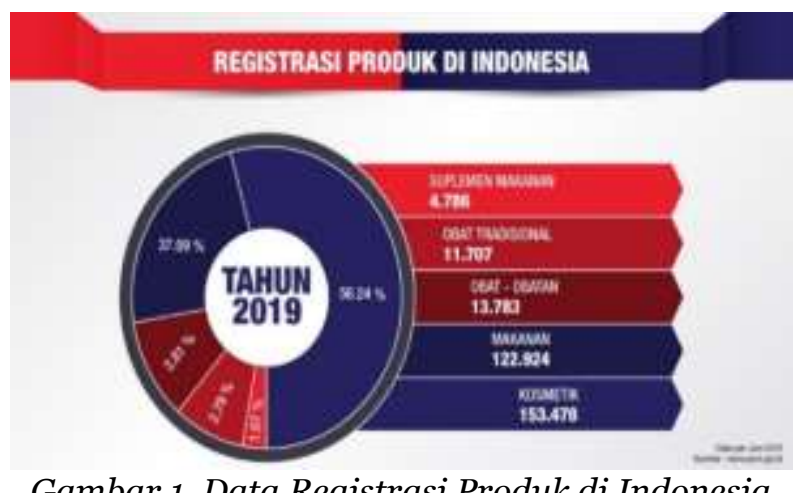

Gambar 1. Data Registrasi Produk di Indonesia Sumber : www.pom.go.id (2019)

Pada gambar di atas mengungkapkan bahwa sebagian besar pendaftaran produk adalah untuk kosmetik. Hal ini menarik karena kategori menurut laporan BPOM, kosmetik ini hampir tidak membuahkan hasil di tahun 2012 sampai 2013. Hal ini kemudian diikuti oleh produk makanan dan obatobatan. Obat tradisional dan suplemen makanan mendapatkan bagian terkecil.

Pangsa pasar yang mempunyai potensi besar juga menjadi alasan banyaknya produsen baru kosmetik di Indonesia. Jumlah penduduk sekitar 269 
juta jiwa, menjadikan Indonesia pasar yang menjanjikan bagi perusahaan kosmetik. Kendati mayoritas industri kosmetik membidik target konsumen utama kaum wanita, sebuah laporan dari Euromonitor International, Markets of the Future: $A S E A N$ in 2020 mengatakan, bahwa untuk laju pertumbuhan majemuk tahunan, Indonesia akan menjadi market kecantikan dengan pertumbuhan tercepat di Asia (Jawa Pos).

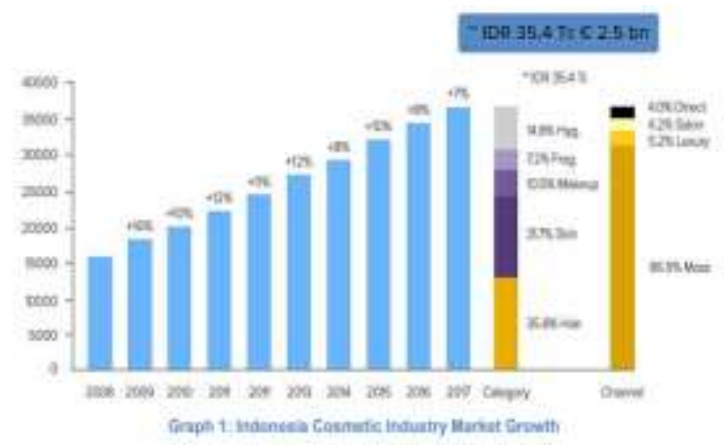

Gambar 2. Pertumbuhan Pasar Industri Kosmetik Sumber : Beauty Mass Survey (2018)

Mengingat tingkat pertumbuhan PDB yang konsisten di atas 5\% dalam dua tahun terakhir, para analisis memperkirakan 10 hingga 15 tahun ke depan pasar Asia termasuk Indonesia menerapkan teknologi digital untuk menciptakan nilai tambah termasuk dalam produk kosmetik. Kosmetik-kosmetik lokal kini mulai bersaing dengan produk luar negeri. Animo masyarakat dalam memilih dan menggunakan produk lokal juga meningkat, masyarakat mulai menghargai dan melirik produk lokal, termasuk produk dari industri lokal karena kemajuannya. Berdasarkan survei yang dilakukan Euro Monitor dan Mirae Asset Sekuritas, konsumen Indonesia cenderung memilih produk kecantikan berdasarkan merek dan image di masyarakat luas.

Salah satu kosmetik yang sedang popular di kalangan masyarakat adalah produk dengan brand Emina. PT Paragon Technology \& Innovation mengeluarkan tiga brand kosmetik, salah satunya yakni Emina. Brand ini dirilis pada tahun 2015, dan tergolong masih baru. Namun Emina dapat bersaing dengan produk-produk lokal yang lebih dulu popular di Indonesia. Berikut perbandingan brand Emina dengan 5 merek kosmetik lokal pada pencarian 12 bulan terakhir:

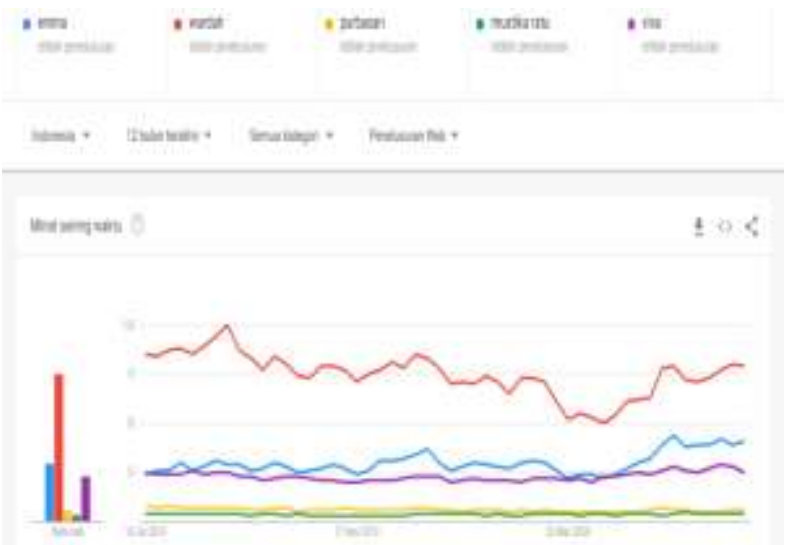

Gambar 3. Perbandingan Emina dengan Merek Lokal Lain Sumber : Google Trends

Pada gambar di atas dapat dilihat bahwa popularitas Emina mulai bulan Juli 2019 hingga Maret 2020 berada di nomor dua dibandingkan produk popular yang sudah lama di Indonesia yakni, Purbasari, Mustika Ratu, dan Viva. Selain itu pada gambar, grafik popularitas Emina meningkat. Purbasari, Mustika Ratu, dan Viva memang mulai menemui persaingan ketat dengan brand-brand lokal pendatang baru. Salah satu yang harus diwaspadai adalah Emina. Emina mengangkat gaya kosmetik yang chic untuk remaja dan mengklaim produknya mempunyai tekstur yang ringan untuk pemakai kosmetik pemula. Emina mengambil pangsa pasar remaja untuk produk-produknya. Adapun koleksi kosmetik yang dimiliki oleh brand Emina yang terbilang baru dalam jagad kosmetik ini sangat beragam dan cukup lengkap, mulai perawatan kulit wajah, kosmetik, hingga perawatan badan. 
Pemanfaatan teknologi dan internet pada revolusi 4.0 ini mampu mendorong pemasaran produk-produk yang ditawarkan. E-commerce sebagai media penjualan produk kini marak untuk digunakan. Pengguna e-commerce juga semakin banyak karena kemudahan dalam memperoleh produk yang diinginkan. Pada penggunaan e-commerce ada beberapa perspektif dari konsumen.

Salah satu online market place yang banyak digunakan adalah Shopee. Shopee merupakan salah satu marketplace yang menduduki peringat lima teratas di Indonesia. Adapun pemilihan layanan market place berdasarkan perbedaan gender menggambarkan perbandingan untuk peminat di masing-masing platform. Berikut perbandingan e-commerce dan online marketplace di Indonesia berdasarkan enam peringkat aplikasi teratas di play store :

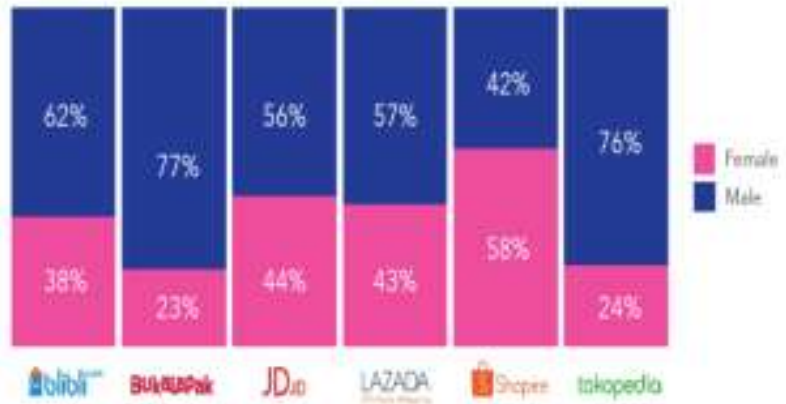

Gambar 4. Perbandingan Pemilihan Platform ECommerce Berdasarkan Gender Sumber : Dailysocial.id (2018)

Pada Gambar 4 dapat dilihat bahwa pengguna Shopee diminati oleh perempuan sebesar $58 \%$, dan laki-laki $42 \%$. Hal tersebut dapat menjadi peluang bagi perusahaan yang memproduksi produk yang ditujukan untuk perempuan, seperti kosmetik.

Shopee sebagai marketplace berhasil mengukuhkan diri sebagai e-commerce paling populer di Indonesia. Berdasarkan laporan iPrice, pada quartal dua tahun 2020 ini Shopee menduduki peringkat pertama pemain besar $e$-commerce.

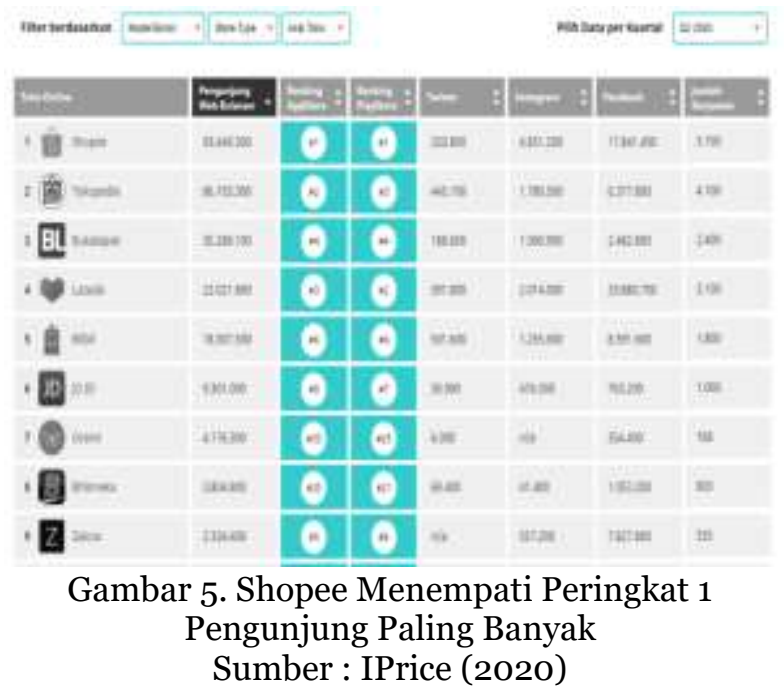

Dapat dilihat bahwa Shopee mampu menggungguli Tokopedia dengan jumlah pengunjung 93.440.300 perbulannya serta mendapat ranking \#1 di AppStore dan PlayStore. Hal ini dapat dimanfaaatkan oleh perusahaan ini untuk memasarkan produknya melalui penggunaan aplikasi $e$ commerce.

Emina sebagai produsen juga menggunakan Shopee sebagai salah satu media pemasarannya. Agar mampu bersaing dengan produsen sejenis, Emina dituntut untuk memiliki strategi yang tepat sehingga bisnisnya dapat bersaing dan memiliki keunggulan dibandingkan dengan para pesaing. Untuk dapat mencapai titik kepuasan konsumen hingga menimbulkan minat beli ulang konsumen, maka Emina juga harus memperhitungkan faktor-faktor yang dapat mempengaruhi hal tersebut, seperti harga, promosi, dan kualitas produk. Namun fokus pada hal tersebut dianggap biasa pada saat ini. Emina harus memberikan pengalaman yang baik kepada pelanggan agar timbul keinginan untuk 
melakukan pembelian ulang di official store Emina pada aplikasi Shopee.

Kepercayaan pelanggan terhadap produk Emina yang ada official store Emina di Shopee, serta ulasan pelanggan pada official store Emina ini akan mempengaruhi minat pelanggan dalam melakukan pembelian ulang.

Kepercayaan pelanggan Menurut Sangadji dan Sopiah (2013:201) mendefinisikan kepercayaa konsumen sebagai semua pengetahuan yang dimiliki oleh konsumen, dan semua kesimpulan yang dibuat oleh konsumen tentang objek, atribut, dan manfaatnya. Kepercayaan pelanggan ini akan menentukan sikap dan minat pembelian ulang terhadap produk yang sudah dibeli.

Sedangkan ulasan produk oleh pelanggan kerap dijadikan bahan pertimbangan untuk melakukan keputusan pembelian di marketplace. Menurut kamus Collins (2018), ulasan pelanggan adalah sebuah laporan di sebuah media di mana seseorang memberi opini atas jasa atau produk yang dibeli. Menurut Ananda (2016) konsep Consumer Online Review terdiri dari tiga variabel, yaitu Attractiveness, Trustworthiness, dan Expertise. Menurut Shimp (2007), Attractiveness merupakan daya tarik yang ada di dalam diri dan dianggap sebagai sesuatu yang menarik untuk dilihat, meliputi keramahan, hal yang menyenangkan, fisik dan pekerjaan. Trustworthiness menurut Shimp (2007) mengacu pada penyampai informasi yang dipandang memiliki kejujuran, integritas, dan sejauh mana dapat dipercaya sehingga audience memiliki kepercayaan terhadap apa yang disampaikan oleh penyampai informasi. Menurut Shimp (2007), Expertise atau keahlian mengacu pada pengetahuan, pengalaman yang dimiliki oleh penyampai informasi yang dipadukan dengan informasi merek produk yang sedang disampaikan. Saat penyampai informasi produk memiliki kemampuan penggabungan pengalaman terdahulu dan informasi produk maka penilai dapat lebih persuasif dalam menarik audience dan dapat diterima sebagai seorang ahli.

Berdasarkan judul dan latar belakang tersebut di atas, maka peneliti merumuskan masalah "Apakah kepercayaan dan ulasan produk berpengaruh secara parsial dan simultan terhadap minat beli ulang Emina pada Official Store Shopee di Kota Surabaya?”. Dengan tujuan untuk mengetahui pengaruh parsial dan simultan variabel kepercayaan dan ulasan produk terhadap minat beli ulang Emina pada Official Store Shopee di Kota Surabaya.

\section{LANDASAN TEORI}

\section{Pemasaran}

Menurut Sudaryono (2016 : 42) Pemasaran adalah suatu perpaduan dari aktivitas-aktivitas yang saling berhubungan untuk mengetahui kebutuhan konsumen melalui penciptaan, penawaran, dan pertukaran produk dan jasa yang bernilai. (Jacklin et al., 2019) menyatakan bahwa manajemen pemasaran merupakan suatu proses yang dimulai dari proses perencanaan, pengarahan, dan pengendalian produk atau jasa, penetapan harga, distribusi, dan promosinya dengan tujuan membantu organisasi dalam mencapai sasarannya.

\section{Kepercayaan}

Menurut Supriyono (2010) Trust adalah kepercayaan pihak tertentu terhadap yang lain dalam melakukan hubungan transaksi berdasarkan suatu keyakinan bahwa orang yang dipercayainya tersebut akan memenuhi segala kewajibannya secara 
baik sesuai yang diharapkan.. Sedangkan menurut (Ilmiyah \& Krishernawan, 2020) kepercayaan merupakan keyakinan terhadap produk yang memiliki atribut dan mendapatkan manfaat dari atribut, dan juga keyakinan bahwa relasi pertukarannya akan memberikan apa yang diinginkan dan dapat diandalkan. Maharani (2010) mengemukakan bahwa terdapat empat indikator dalam variabel kepercayaan yaitu:

1. Kehandalan

Kehandalan merupakan konsisten dari serangkaian pengukuran. Kehandalan dimaksudkan untuk mengukur kekonsistenan perusahaan dalam melakukan usahanya dari dulu sampai sekarang.

2. Kejujuran

Bagaimana perusahaan menawarkan produk barang atau jasa yang sesuai dengan informasi yang diberikan perusahaan kepada konsumennya.

3. Kepedulian

Perusahaan/pemasar yang selalu melayani dengan baik konsumennya, selalu menerima keluhan-keluhan yang dikeluhkan konsumennya, serta selalu menjadikan konsumen sebagai prioritas.

4. Kredibilitas

Kualitas atau kekuatan yang ada pada perusahaan/pemasar

meningkatkan untuk konsumennya.

\section{Ulasan Produk}

Menurut (Ilmiyah \& Krishernawan, 2020) ulasan produk adalah tulisan yang ditulis konsumen pada kolom yang sudah disiapkan oleh e-commerce yang mencerminkan kualitas barang yang sebenarnya, seperti masalah warna, spesifikasi tidak konsisten, masalah penggunaan, atau kualitas tinggi, dan pengalaman yang baik. Sementara itu
(Lackermair (2013) dalam Muhasri (2020)) menyatakan bahwa penilaian tentang produk atau perusahaan yang diberikan oleh konsumen dapat bersifat positif atau negatif, penilaian dibuat sesuai dengan pengalaman orang yang melakukan ulasan tersebut, selain itu dalam ulasan biasa disertai dengan menjelaskan mengenai keuntungan dan kerugian dari membeli produk tersebut. Dari teori di atas dapat diartikan bahwa ulasan produk adalah suatu komentar yang dituliskan oleh konsumen atas produk yang telah dikonsumsi di tempat yang telah disediakan oleh platform e-commerce.

Menurut (Lackermair, Kailer, \& Kanmaz, 2013, p. 2 dalam Sudjatmika, 2017) indikator ulasan produk diantaranya adalah sebagai berikut :

1. Kesadaran (Awareness)

Pembeli sadar akan adanya fitur ulasan produk yang ada di platform $e$ commerce dan menggunakan informasi tersebut dalam proses seleksi.

2. Frekuensi (Frequency)

Pembeli sering menggunakan fitur ulasan produk di platforme-commerce sebagai sumber informasi.

3. Perbandingan (Comparison)

Sebelum membeli, pembeli membaca ulasan produk yang akan dibeli, yang terdapat di platform e-commerce satu demi satu dan membandingkan ulasanulasan tersebut

4. Pengaruh (Effect)

Fitur ulasan produk di platform e commerce memberikan pengaruh terhadap seleksi produk.

\section{Minat Beli Ulang}

Menurut (Faradisa et al., 2016) Minat beli ulang merupakan bagian dari perilaku pembelian, yang selanjutnya akan membentuk loyalitas dalam diri konsumen. 
Selain itu, pelanggan yang memiliki komitmen pada umumnya lebih mudah menerima perluasan produk baru yang ditawarkan oleh perusahaan tersebut. Kesesuaian performa produk dan jasa yang ditawarkan dengan yang diharapkan konsumen akan memberikan kepuasan dan akan menghasilkan minat beli ulang konsumen di waktu yang akan datang. Konsumen yang merasa puas dan yang memutuskan untuk menjadi pelanggan, secara naluriah akan berkomitmen merekomendasikan positif produk tersebut terhadap calon konsumen yang lain terhadap produk tersebut. Sehingga pelanggan yang berkomitmen itu akan berperan dalam pengembangan suatu merek tertentu. Dengan demikian proses evaluasi konsumen terkait performa dan kualitas produk tersebut sangat menentukan tingkat motivasi pembelian ulang terhadap suatu merek. Motivasi tersebut akan menimbulkan keinginan dalam diri konsumen untuk melakukan pembelian ulang atau mungkin meningkatkan jumlah pembeliannya sehingga akan tercipta komitmen yang besar untuk menggunakan kembali produk tersebut. Pembelian ulang konsumen merupakan suatu keputusan konsumen untuk membeli produk lebih dari satu kali di mana keputusan ini juga diiringi faktorfaktor yang mempengaruhinya, terutama tentang informasi mengenai produk yang akan mereka dapatkan. (Tambunan, 2009). Sementara (Bahar \& Sjaharuddin, 2019) menyatakan bahwa minat beli merupakan bagian dari komponen perilaku dalam sikap mengkonsumsi.

Menurut Ferdinand (2002:129) Indikator minat beli dapat diidentifikasi sebagai berikut :

1. Minat transaksional

Kecenderungan seseorang untuk membeli produk.

2. Minat referensial Kecenderungan seseorang untuk mereferensikan produk kepada orang lain.

3. Minat preferensial

Gambaran seseorang terhadap pilihan utama pada suatu produk tertentu

4. Minat eksploratif

Minat seseorang terhadap suatu produk tertentu dan dengan itu ia mencari berbagai informasi mengenai keunggulan produk yang diinginkannya tersebut.

\section{Kerangka Pemikiran}

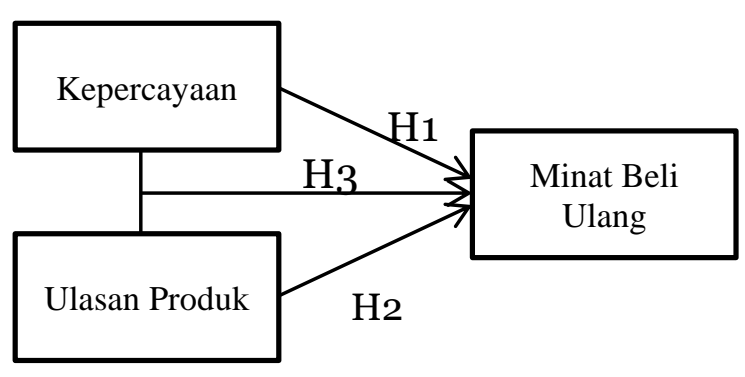

Gambar 6. Kerangka Pemikiran

\section{Hipotesis}

Berdasarkan kerangka pemikiran tersebut, maka penulis merumuskan beberapa hipotesis penelitian sebagai berikut :

H1: kepercayaan memiliki pengaruh positif dan signifikan terhadap minat beli ulang.

H2: ulasan produk memiliki pengaruh yang positif dan signifikan terhadap minat beli ulang.

H3: kepercayaan dan ulasan produk memiliki pengaruh secara simultan dan signifikan terhadap minat beli ulang.

\section{METODE PENELITIAN}

Metode penelitian yang digunakan dalam penelitian ini adalah metode penelitian kuantitatif dengan menggunakan 
analisis uji $t$, uji $F$, dan regresi linier berganda. Teknik pengumpulan data dalam penelitian ini menggunakan metode survey sedangkan untuk pengumpulan data dilakukan dengan menggunakan kuesioner. Populasi adalah objek atau subjek yang berada pada suatu wilayah topik penelitian dan memenuhi syarat-syarat tertentu berkaitan dengan masalah penelitian (Djam'an Satori dan Aan Komariah, 2017:46), yang mana populasi penelitian ini adalah seluruh konsumen produk Emina pada Official Store Shopee yang ada di Kota Surabaya, Jawa Timur. Di mana tidak diketahui secara pasti jumlah populasi yang ada.

Metode pengambilan sampel yang dilakukan pada penelitian ini adalah non probability sampling artinya semua anggota populasi belum tentu memiliki kesempatan untuk menjadi sampel. Sementara itu penentuan sampel yang digunakan yaitu purposive sampling yang mana menurut Sugiyono (2017:85) purposive sampling adalah teknik penentuan sampel dengan pertimbangan tertentu. Beberapa pertimbangan dalam penelitian ini, antara lain :

1. Konsumen yang memiliki aplikasi Shopee

2. Konsumen produk Emina di Shopee yang berdomisili di Kota Surabaya

3. Konsumen produk Emina di Shopee yang telah melakukan transaksi pembelian paling sedikit satu (1) kali.

Dalam hal ini jumlah populasi tidak diketahui maka penentuan sampel menggunakan rumus unknown population (Ferdinand dalam Saripa, 2019) sebagai berikut :

Keterangan :

$$
n=\frac{Z^{2}}{4 \mu^{2}}
$$

$\mathrm{n} \quad=$ Jumlah sampel
$\mathrm{Z}=$ Tingkat keyakinan sampel yang dibutuhkan dalam penelitian (

pada $\quad 5 \%$ atau derajat keyakinan ditentukan 95\% maka $Z=1,96$ )

$\mu \quad=$ margin of eror, tingkat kesalahan yang dapat ditoleransi (ditentukan $\quad 10 \%$ atau 0,1 )

Dengan menggunakan rumus di atas maka diperoleh perhitungan sebagai berikut:

$$
\begin{gathered}
n=\frac{Z^{2}}{4 \mu^{2}} \\
n=\frac{1,96^{2}}{4(0,1)^{2}} \\
n=96,4
\end{gathered}
$$

Dari hasil perhitungan tersebut maka diketahui besar sampel yang diperlukan adalah 96,4 dan dibulatkan menjadi 96 responden. Untuk mendapatkan hasil yang lebih akurat dan representatif maka peneliti mengambil sampel sebanyak 100 responden.

\section{HASIL PENELITIAN DAN PEMBAHASAN}

Tabel 1. Uji Validitas

\begin{tabular}{lll}
\hline Variabel & Item & R hitung \\
\hline Kepercayaan & X1.1 & 0,701 \\
\hline & X2.2 & 0,668 \\
\hline & X3.3 & 0,766 \\
\hline & X4.4 & 0,642 \\
\hline Ulasan & X2.1 & 0,703 \\
\hline & X2.2 & 0,659 \\
\hline & X2.3 & 0,83 \\
\hline Minat Beli & X2.4 & 0,751 \\
\hline & Y.1 & 0,767 \\
\hline & Y.2 & 0.789 \\
\hline & Y.3 & 0,761 \\
\hline & Y.4 & 0,608 \\
\hline
\end{tabular}

Sumber : Data diolah (2020)

Berdasarkan tabel 1 seluruh item variable bebas dan terikat pada uji validitas memiliki nilai $r$ hitung $\geq \mathrm{r}$ table $(0,1960)$, maka dinyatakan valid. 
Berdasarkan tabel 2 hasil uji reliabilitas di atas, dapat diketahui bahwa seluruh butir pernyataan menghasilkan nilai Cronbach's Alpha yang nilainya lebih tinggi dari 0.6 sehingga semua variabel dalam penelitian ini, yaitu kepercayaan, ulasan produk, dan minat beli ulang dinyatakan reliabel dan kuesioner yang digunakan dalam penelitian sudah representatif, yaitu dapat dipercaya dan diandalkan.

Tabel 2. Uji Reliabilitas

\begin{tabular}{lll}
\hline Variabel & \multicolumn{2}{l}{ Reliabilitas } \\
\cline { 2 - 3 } $\begin{array}{l}\text { Cronbach's } \\
\text { Alpha }\end{array}$ & Sig \\
\hline $\begin{array}{l}\text { Kepercayaan } \\
\text { (X1) }\end{array}$ & 0,64 & 0,6 \\
\hline $\begin{array}{l}\text { Ulasan Produk } \\
\text { (X2) }\end{array}$ & 0,718 & 0,6 \\
\hline $\begin{array}{l}\text { Minat Beli Ulang } \\
(\text { Y) }\end{array}$ & 0,707 & 0,6 \\
\hline
\end{tabular}

Sumber : Data diolah (2020)

Dari tabel 3 hasil uji normalitas menggunakan metode KolmogorovSmirnov menunjukkan nilai signifikan $>$ 0,05 yaitu 0,2 maka dapat dinyatakan bahwa data terdistribusi secara normal.

\begin{tabular}{lll}
\multicolumn{3}{l}{ Tabel 3. Uji Normalitas Kolmogorov - Smirnov } \\
\hline $\mathrm{N}$ & & 100 \\
\hline Normal & Mean & .0000000 \\
\cline { 2 - 3 } Parameters & Std. & 2.13106202 \\
& $\begin{array}{l}\text { Deviation } \\
\end{array}$ & \\
\hline Most & Absolute & .047 \\
\cline { 2 - 3 } Extreme & Positive & .032 \\
\cline { 2 - 3 } Differences & Negative & -.047
\end{tabular}

\begin{tabular}{ll}
\hline Test Statistic & .047 \\
\hline Asymp. Sig. (2-tailed) & $.200^{\mathrm{c}, \mathrm{d}}$ \\
\hline Sumber : Data diolah (2020) &
\end{tabular}

Pada tabel 4 hasil dari uji Multikolinieritas terdapat nilai VIF pada kedua variabel bebas $<10$, yaitu 1,101 untuk kepercayaan dan ulasan produk. Oleh karena itu, data dalam penelitian ini tidak terdapat multikolinieritas. Selain dengan membandingkan nilai VIF dengan batas nilai 10, uji multikolinieritas dapat dinilai dari besarnya angka tolerance dengan nilai $>$ o.1, jika nilai pada tolerance lebih besar dari 0.1 maka variabel bebas tidak memiliki sifat multikolinieritas. Berdasarkan perhitungan, dua variabel bebas dalam penelitian ini memiliki nilai tolerance lebih tinggi dibanding 0.1 yaitu 0,908 sehingga semua variabel bebas tidak menunjukkan gejala multikolinieritas.

Tabel 4. Uji Multikolinearitas

\begin{tabular}{lll}
\hline Model & Statistic & Cilinieraity \\
\hline & Tolerance & VIF \\
\hline Kepercayaan & 0,908 & 1,01 \\
\hline Ulasan Produk & 0,908 & 1,101 \\
Sumber : Data diolah $(2020)$ &
\end{tabular}

Pada gambar 7 grafik scatterplot di bawah ini dapat dilihat bahwa persebaran data tidak membentuk pola seperti bergelombang, menyebar, dan menyempit. Selain itu, titik tersebar rata di atas dan di bawah nilai nol pada sumbu Y. Berdasarkan keadaan tersebut, dapat dinyatakan bahwa data terdistribusi normal dan tidak terjadi gejala heteroskedastisitas.

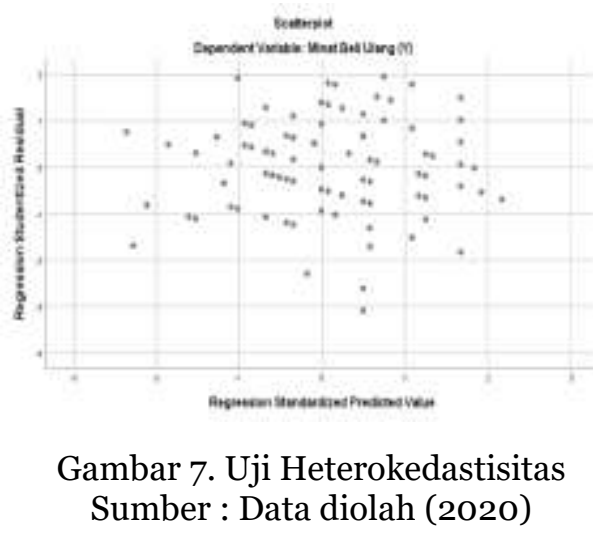

Berdasarkan tabel 5 nilai signifikansi (Sig.) yang dihasilkan lebih kecil dari probabilitas pada variabel kepercayaan (X1) yakni 0,000 lebih kecil dari 0,05. Hal teresbut menunjukkan adanya pengaruh 
signifikan secara parsial antara variabel bebas dengan variabel terikat atau $\mathrm{H} 1$ diterima. Berdasarkan nilai t hitung dengan $\mathrm{t}$ tabel di atas, hasil nilai $\mathrm{t}$ hitung variabel kepercayaan sebesar 5,014 dan $t$ tabel sebesar 1,984 berarti t hitung $>\mathrm{t}$ tabel dapat disimpulkan bahwa H1 diterima.

Untuk variabel ulasan produk (X2) nilai Signifikansi (Sig.) yang dihasilkan lebih besar dari probabilitas yakni o,436 > dari o,05. Hal tersebut menunjukkan tidak adanya pengaruh signifikan secara parsial antara variabel bebas dengan variabel terikat atau H2 ditolak. Berdasarkan nilai t hitung dengan $t$ tabel di atas, hasil nilai $t$ hitung variabel ulasan produk sebesar 0,781 dan $t$ tabel sebesar 1,984 berarti $t$ hitung $<\mathrm{t}$ tabel dapat disimpulkan bahwa H2 ditolak.

Tabel 5. Uji T

\begin{tabular}{ccc}
\hline Model & T hitung & Sig \\
\hline Kepercayaan & 5,014 & 0,000 \\
\hline Ulasan Produk & 0,781 & 0,436
\end{tabular}

Sumber : Data diolah (2020)

Berdasarkan tabel 6 output di bawah ini diketahui nilai signifikansi untuk pengaruh X1 dan X2 secara simultan terhadap Y adalah sebesar $0,000<0,05$ dan nilai $\mathrm{F}$ hitung 12,870 > F tabel sebesar 3,09 sehingga dapat disimpulkan bahwa $\mathrm{H}_{3}$ diterima yang berarti terdapat pengaruh $\mathrm{X} 1$ dan X2 secara simultan terhadap Y.

Tabel 6. Uji F

\begin{tabular}{|c|c|c|c|c|c|}
\hline Model & $\begin{array}{l}\text { Sum of } \\
\text { Squares }\end{array}$ & $\mathrm{df}$ & $\begin{array}{l}\text { Mean } \\
\text { Square }\end{array}$ & $\mathrm{F}$ & Sig. \\
\hline $\begin{array}{l}1 \text { Regression } \\
\text { Residual } \\
\text { Total }\end{array}$ & $\begin{array}{l}119.309 \\
449.601 \\
568.910\end{array}$ & $\begin{array}{l}2 \\
97 \\
9 \\
9\end{array}$ & $\begin{array}{l}59.654 \\
4.635\end{array}$ & 12.870 & $.000^{\mathrm{a}}$ \\
\hline
\end{tabular}

Sumber : Data diolah (2020)
Tabel 7. Uji regresi Linear Berganda

\begin{tabular}{|c|c|c|c|c|c|}
\hline \multirow[b]{2}{*}{ Model } & \multicolumn{2}{|c|}{$\begin{array}{l}\text { Unstandard } \\
\text { ized } \\
\text { Coefficients }\end{array}$} & \multirow{2}{*}{\begin{tabular}{|l} 
Standardized \\
Coefficients
\end{tabular}} & \multirow[b]{2}{*}{$\mathrm{t}$} & \multirow[b]{2}{*}{ Sig. } \\
\hline & B & $\begin{array}{l}\text { Std. } \\
\text { Error }\end{array}$ & & & \\
\hline $\begin{array}{c}1 \text { (Cons } \\
\operatorname{tant})\end{array}$ & 5.776 & 2.521 & & 2.291 & .024 \\
\hline $\begin{array}{l}\text { Keper } \\
\text { cayaan } \\
(\mathrm{X} 1)\end{array}$ & .645 & .129 & .475 & 5.014 & .000 \\
\hline $\begin{array}{l}\text { Ulasan } \\
\text { Produk } \\
(\mathrm{X} 2)\end{array}$ & -.091 & .117 & -.074 & -.781 & .436 \\
\hline
\end{tabular}

Sumber : Data diolah (2020)

Berdasarkan tabel 7 di atas, Persamaan Regresi Linier Berganda sebagai berikut:

$\mathrm{Y}=5,776+0,645 \mathrm{X} 1-0,091 \mathrm{X} 2$

Hasil persamaan linier berganda di atas diuraikan antara lain yaitu:

a. Nilai konstanta bernilai 5,776 diartikan bahwa apabila variabel kepercayaan dan ulasan produk konstan, maka variabel minat beli ulang akan sebesar 5,776.

b. Koefisien regresi kepercayaan (X1) bernilai positif 0,645 dapat diartikan bahwa jika terdapat kenaikan satu poin (1\%) akan meningkatkan minat beli ulang sebesar 0,645. Sebaliknya jika mengalami penurunan satu poin (1\%) akan menurunkan minat beli ulang sebesar 0,645 dengan asumsi variabel lain konstan.

c. Koefisien regresi ulasan produk (X2) bernilai negatif -0,091 dapat diartikan bahwa jika terdapat kenaikan satu poin (1\%) akan menurunkan minat beli ulang sebesar 0,091. Sebaliknya jika mengalami penurunan satu poin (1\%) akan menaikkan minat beli ulang sebesar 0,091 dengan asumsi variabel lain konstan. Koefisien bernilai negatif artinya terjadi hubungan negatif antara ulasan

d. produk dengan minat beli ulang. 
e. Hasil analisis diketahui bahwa variabel independen yang paling berpengaruh secara dominan yaitu variabel kepercayaan dengan koefisien regresi 0,645 .

Berdasarkan tabel 8 diketahui nilai koefisien determinan sebesar 0,210. Nilai $R$ square 0,210 ini berasal dari pengkuadratan nilai koefisien korelasi atau " $R$ ", yaitu 0,458 . Besarnya angka koefisien determinasi ( $R$ square) sama dengan 21,0\%. Angka tersebut mengandung arti bahwa variabel kepercayaan $\left(\mathrm{X}_{1}\right)$ dan ulasan produk $\left(\mathrm{X}_{2}\right)$ mempengaruhi minat beli ulang $(\mathrm{Y})$ sebesar $21,0 \%$. Sisanya $79,0 \%$ dipengaruhi oleh variabel yang tidak diteliti. Hasil koefisien korelasi (R) 0,458 menunjukkan bahwa hubungan antara variabel independen tersebut secara bersama-sama terhadap variabel dependen memiliki hubungan yang cukup kuat dengan tingkat interval koefisien (0,40-0,599).

Tabel 8. Uji Koefisien Determinasi

\begin{tabular}{|l|l|l|l|l|}
\hline Model & $\mathrm{R}$ & $\begin{array}{l}\mathrm{R} \\
\text { Square }\end{array}$ & $\begin{array}{l}\text { Adjusted } \\
\text { R Square }\end{array}$ & $\begin{array}{l}\text { Std Error } \\
\text { of the } \\
\text { Estimated }\end{array}$ \\
\hline 1 & .458 & .210 & .193 & 2.153 \\
\hline
\end{tabular}

Sumber : Data diolah (2020)

\section{Pembahasan}

\section{Kepercayaan terhadap Minat Beli Ulang}

Hipotesis 1 diterima karena t hitung 5,014 $>\mathrm{t}$ tabel 1,984 dengan signifikansi hitung $0,000<0,05$, dan nilai koefisien regresi 0,645 dapat diartikan bahwa kepercayaan berpengaruh positif dan signifikan terhadap minat beli ulang. Semakin tinggi kepercayaan pelanggan maka semakin tinggi pula minat beli ulang terhadap produk Emina pada Official Store Shopee di Kota Surabaya. Hal tersebut menunjukkan bahwa produk Emina di
Official Store Shopee dapat dipercaya konsumen dalam hal kehandalan, kejujuran, kepedulian, dan kredibilitas dari transaksi belanja online tersebut.

Menurut Malau (2016:301) Kepercayaan pembeli sebagai kunci terpenting karena aktivitas bidang usaha yang dijalankan adalah melalui online, penjual dan pembeli tidak berhadapan secara langsung. Kepercayaan merupakan unsur yang paling penting kaitan dengan belanja online karena kepercayaan mampu memberikan dorongan bagi konsumen untuk senantiasa membeli suatu produk tertentu.

Hasil penelitian ini didukung penelitian Adinata dan Yasa (2018) menjelaskan bahwa adanya hubungan positif antara kepercayaan dengan niat beli ulang konsumen secara online. Penelitian Ilmiyah dan Krishernawan (2020) menjelaskan bahwa kepercayaan berpengaruh positif dan signifikan terhadap keputusan pembelian. Penelitian Tilaar, dkk (2018) menjelaskan bahwa kepercayaan berpengaruh terhadap minat beli online. Semakin tinggi kepercayaan konsumen terhadap suatu produk maka semakin tinggi juga kesetiaan pelanggan terhadap produk tersebut.

\section{Ulasan Produk Terhadap Minat Beli Ulang}

Hipotesis 2 ditolak karena t hitung $-0,781<\mathrm{t}$ tabel 1,984 dengan nilai signifikan $0,436>0,05$, dan nilai koefisien regresi o,091 dapat diartikan bahwa tidak ada pengaruh dan signifikansi ulasan produk terhadap minat beli ulang. Hal ini menerangkan bahwa fitur ulasan produk dari konsumen yang pernah membeli tidak terlalu diperhatikan oleh konsumen untuk melakukan pembelian. 
Hasil ini mendukung penelitian oleh Sudjatmika (2017) menjelaskan bahwa ulasan produk tidak berpengaruh terhadap keputusan pembelian. Penelitian Ilmiyah dan Krishernawan (2020) yang menjelaskan bahwa ulasan produk tidak memiliki pengaruh terhadap keputusan pembelian.

Penelitian ini berbeda dari hasil penelitian oleh Rahayu, dkk, (2020) dengan judul "Pengaruh Harga, Ulasan Produk, Kemudahan Penggunaan, dan Keamanan Transaksi Terhadap Keputusan Pembelian Secara Online di Shopee" yang menjelaskan bahwa ulasan produk berpengaruh positif terhadap keputusan pembelian.

\section{Kepercayaan dan Ulasan Produk Terhadap Minat Beli Ulang}

Hasil penelitian nilai $\mathrm{F}$ hitung 12,870 dan F tabel sebesar 3,09 $(12,870>3,09)$. Signifikan 0,000 (0,000 < 0,05) maka hipotesis yang menjelaskan bahwa "kepercayaan dan ulasan produk memiliki pengaruh secara simultan dan signifikan terhadap minat beli ulang Emina pada Official Store Shopee di Kota Surabaya" dapat diterima.

Menurut (Tambunan, 2009) Pembelian ulang konsumen merupakan suatu keputusan konsumen untuk membeli produk lebih dari satu kali di mana keputusan ini juga diiringi faktor-faktor yang mempengaruhinya, terutama tentang informasi mengenai produk yang akan mereka dapatkan.

Terdapat dua pengaruh seseorang untuk melakukan pembelian ulang, yaitu kepercayaan dan ulasan produk. Kepercayaan merupakan keyakinan akan suatu produk dilihat dari segi kualitas dan keandalan produk tersebut, yang mana diharapkan mampu memenuhi harapan dari konsumen. Kemudian ulasan produk, yang mana merupakan komentar yang diberikan oleh konsumen setelah melakukan pembelian suatu produk. Apabila ulasan yang diberikan positif maka akan mempengaruhi konsumen selanjutnya untuk melakukan pembelian ulang produk tersebut.

\section{Variabel Kepercayaan Berpengaruh Paling Dominan Terhadap Minat Beli Ulang}

Variabel kepercayaan merupakan variabel yang memiliki pengaruh paling besar dan dominan terhadap minat beli ulang produk Emina pada Official Store Shopee di kota Surabaya. Dibuktikan oleh hasil analisis regresi linier berganda yang mendapatkan nilai 0,645 dan $t$ hitung sebesar 5,014.

Penelitian ini mendukung hasil penelitian dari Tilaar, dkk, (2020) yang membuktikan bahwa variabel kepercayaan adalah variabel yang paling dominan mempengaruhi minat beli secara online

\section{KESIMPULAN}

\section{Kesimpulan}

Berdasarkan pembahasan pada babbab sebelumnya maka kesimpulan dalam penelitian ini adalah :

1. Hipotesis pertama ada pengaruh dan signifikan kepercayaan terhadap minat beli ulang. Semakin tinggi kepercayaan produk oleh pelanggan dari segi kehandalan, kejujuran, kepedulian, dan kredibilitas dari transaksi belanja online tersebut maka semakin tinggi minat beli ulang produk Emina pada Official Store Shopee di Kota Surabaya. 
2. Hipotesis kedua tidak ada pengaruh dan tidak signifikan ulasan produk terhadap minat beli ulang, menurun atau meningkatnya indikator fitur ulasan produk oleh pelanggan yang ada dalam marketplace online tidak mempengaruhi minat beli ulang produk Emina pada Official Store Shopee di Kota Surabaya.

3. Hipotesis ketiga ada pengaruh secara simultan dan signifikan kepercayaan dan ulasan produk terhadap minat beli ulang produk Emina pada Official Store Shopee di Kota Surabaya. Semakin tinggi kepercayaan pelanggan dengan ulasan produk oleh pelanggan terhadap produk-produk yang ditawarkan Emina di Official Store Shopee akan mempengaruhi minat beli ulang pelanggan di Kota Surabaya. Pada penelitian ini variabel kepercayaan berpengaruh paling dominan terhadap minat beli ulang.

\section{Saran}

1. Pihak Emina sebaiknya mempertahankan kepercayaan pada produk-produk yang ditawarkan untuk menjaga minat beli ulang pelanggan pada Official Store Emina di Shopee. Selain kepercayaan, Emina diharapkan dapat melakukan promosi kosmetik yang baik, kesesuaian produk dengan yang ditawarkan untuk menarik minat beli ulang pelanggan.

2. Bagi peneliti selanjutnya, diharapkan menambah variabel keamanan data pelanggan dalam melakukan transaksi, dikarenakan pelannggan juga memperhatikan keamanan dalam melakukan transaksi belanja online.

\section{DAFTAR PUSTAKA}

Adinata, K. J., \& Yasa, N. N. K. (2018). Fakultas Ekonomi dan Bisnis
Universitas Udayana, Bali, Indonesia ABSTRAK Perkembangan teknologi informasi dan komunikasi di Indonesia semakin berkembang dan meningkat setiap tahunnya . Indonesia sendiri memiliki sekitar 132 , 7 juta pengguna sarana inte. $7(8)$, 4153-4180.

Ferdinand, 2002, Metode Penelitian Manajemen : Pedoman penelitian untuk Skripsi, Tesis, dan Disertasi Ilmu Manajemen, Semarang : Badan Penerbit Universitas Diponegoro.

Maharani, Astri Dhiah, Analisis Pengaruh Kepercayaan Terhadap Loyalitas Nasabah Tabungan Bank Mega Syariah Cabang Semarang (Skripsi), Semarang : Universitas Diponegoro Semarang, 2010.

Muhasri, A. (2020). PENGARUH ULASAN PELANGGAN, HARGA, DAN KUALITAS PELAYANAN TERHADAP KEPUTUSAN PEMBELIAN PRODUK KOSMETIK DI SHOPEE (Studi Kasus Pada Mahasiswi Universitas Pertamina).

Rahayu, H., Adi Sismanto, \& Arianto, T. (2020). THE EFFECT OF PRICES, PRODUCT REVIEWS , EASE OF USE AND SECURITY OF TRANSACTIONS ON PURCHASING DECISIONS ONLINE IN SHOPEE PENGARUH HARGA , ULASAN PRODUK , KEMUDAHAN PENGGUNAAN , SECARA O NLINE DI SHOPEE ( Studi Kasus Mahasiswa Fakultas Ekonomi Manajeme. 2, 3448.

Saripa. 2019. Pengaruh Ulasan Dan Penilaian Produk Terhadap Keputusan Pembelian Melalui Tokopedia (Studi Kasus 3 Kecamatan Dikota Makassar). Skripsi. Sekolah Tinggi Ekonomi Nobel Indonesia,

Satori, Djam'an dan Aan Komariah. 2017. Metodologi Penelitian Kualitatif. Bandung: Alfabeta 
Sudaryono.2016. Manajemen Pemasaran Teori dan Implementasi.Yogyakarta: CV Andi Offset

Sudjatmika, F. V. (2017). Pengaruh Harga, Ulasan Produk, Kemudahan, dan Keamanan Terhadap Keputusan Pembelian Secara Online di Tokopedia.com. Agora, 5(1), $1-7$. http://studentjournal.petra.ac.id/inde x.php/manajemenbisnis/article/view/5227\%oAhttp://st udentjournal.petra.ac.id/index.php/m anajemenbisnis/article/view/5227/4814

Sugiyono, 2017. Metode Penelitian Bisnis (Kuantitatif, Kualitatif, dan $R \& D$ ). Bandung: Alfabeta

Supriyono. (2010). KEPERCAYAAN DAN MINAT BELI DI SUB FORUM JUAL BELI www.kaskus.us. 1O(2), 73-82.

Tambunan, S. (2009). MINAT BELI ULANG KARTU PERDANA NOMOR CANTIK SIMPATI ( STUDI DICOMTECH SHOP SURABAYA ).

Tilaar, F., Lapian, 2S.L.H.V. Joyce, \& Roring, F. (2018). Pengaruh Kepercayaan, Dan Motivasi Terhadap Minat Beli Pengguna Shoppe Secara Online Pada Anggota Pemuda Gmim Zaitun Mahakeret. Jurnal EMBA: Jurnal Riset Ekonomi, Manajemen, Bisnis Dan Akuntansi, 6(4), 20282037.

https://doi.org/10.35794/emba.v6i4.2 0932 